\title{
RNAi AND mIRNA PATHWAYS IN ANNELIDS AND MOLLUSCS
}

Keywords: dsRNA, PKR, Dicer, TARBP2, PACT

\author{
PETR SVOBODA \\ Institute of Molecular Genetics, Academy of Sciences of the Czech Republic, \\ Videnska 1083, 14220 Prague 4, Czech Republic \\ Correspondence to: Petr Svoboda, Institute of Molecular Genetics ASCR, \\ Videnska 1083, 14220 Prague 4, Czech Republic, tel. \# +420 241063147, \\ e-mail: svobodap@img.cas.cz.
}

\begin{abstract}
RNA silencing denotes sequence-specific repression mediated by small RNAs. In metazoa, there are two mechanistically closely related pathways: RNA interference (RNAi) and microRNA (miRNA) pathway. The miRNA pathway regulates endogenous protein-coding gene expression and has been implicated in many biological processes. RNAi generally serves as a form of innate immunity targeting viruses and mobile elements. This review is summarizing information about RNAi and miRNA pathways in protostome phyla: Annelida and Mollusca. The molecular mechanisms of dsRNA and miRNA pathways in annelids remain largely unexplored. The available information points towards coexistence of miRNA and RNAi pathways, however, their integration or genetic separation remain unclear. Molluscs are an interesting taxon, which appears to have a unique setup of RNA silencing possibly employing a single Argonaute protein while it also employs interferon-like pathway elements.
\end{abstract}

\section{Introduction}

The mechanistical principles of vertebrate miRNA and RNAi pathways were introduced in the first review of this series (Svoboda, 2019) and in further detail elsewhere (Bartel, 2018), I will focus here directly on features of these pathways reported from Annelid and Molluscs taxons, which do not have common model species, which would be investigated in depth like C. elegans or Drosophila. The review is divided into Annelid and Molluscs parts. In each of them, I'll review published data concerning components of miRNA and RNAi pathways and discuss biological roles of the two pathways. 


\section{Annelids}

Annelids are coelomate protostome worms whose body is organized into a series of ringshaped repetitive segments. $\sim 15000$ annelid species are grouped into three classes: Polychaeta (bristle worms, e.g. Platynereis), Oligochaeta (earthworms, e.g. Lumbricus), and Hirudinea (leeches, e.g. Hirudo). Literature on RNA silencing and dsRNA pathways is extremely limited. There were under twenty publications dealing with small RNAs, most of which was related to detection of miRNAs.

\section{Dicer}

There was no publication concerning Dicer structure or function in annelids, thus all information provided here had to be extracted from genomic databases. Blast search of annelid entries in Genbank (query: murine Dicer protein, algorithm: tblastn, database: Nucleotide collection $\mathrm{nr} / \mathrm{nt}$, results restricted to Annelida (taxid:6340)) identified a single mRNA XM_009031272 from the leech Helobdella robusta encoding a 1316 aa Dicer protein which lacked $\sim 400$ aminoacids at the N-terminus. The protein contained HELICc domain at the N-terminus but lacked the N-terminal DExD domain. Thus, this Dicer is structurally reminiscent of the N-terminally truncated Dicer capable of producing endo-siRNAs (Flemr et al., 2013). Importantly, analysis of Helobdella robusta genomic sequence identified a single Dicer gene on a contig ref|NW_008705401.1|, which also carried the entire N-terminus, which was lacking in the identified mRNA. This would imply a similar scenario as observed in mouse oocytes - Dicer encodes two protein isoforms, where the longer one is adapted for the production of miRNAs, while the shorter can produce both, miRNAs and siRNAs. However, this information would need to be validated experimentally and it needs to be also tested how common would be this scenario for annelids in general. Finally, annelid Dicer also produces miRNAs with median length of 22 nucleotides as estimated from the miRBase data (Kozomara and Griffiths-Jones, 2014) (Fig. 1).

\section{dsRBPs}

There is no literature concerning dsRBP proteins participating in RNA silencing, Rosani et al. suggest that annelids employ a single TARBP2 homolog (Rosani et al., 2016).

\section{Argonaute proteins}

Likewise, there is essentially no information regarding the AGO subfamily of Argonaute proteins. There is a study of protein components in molluscs, which included two annelid species and found that annelids have three (Capitella) and four (Helobdella) Argonaute proteins from both, PIWI and AGO clades (Rosani et al., 2016). There are five papers concerning Argonaute, however of the PIWI clade, which is functioning in the germline (Giani et al., 2011; Kozin and Kostyuchenko, 2015; Ozpolat and Bely, 2015; Sugio et al., 2008; Weigert et al., 2013). Blast search of Helobdella genome identified two AGO paralogs (XM_009021176.1 and XM_009031816.1) and two possible PIWI proteins 

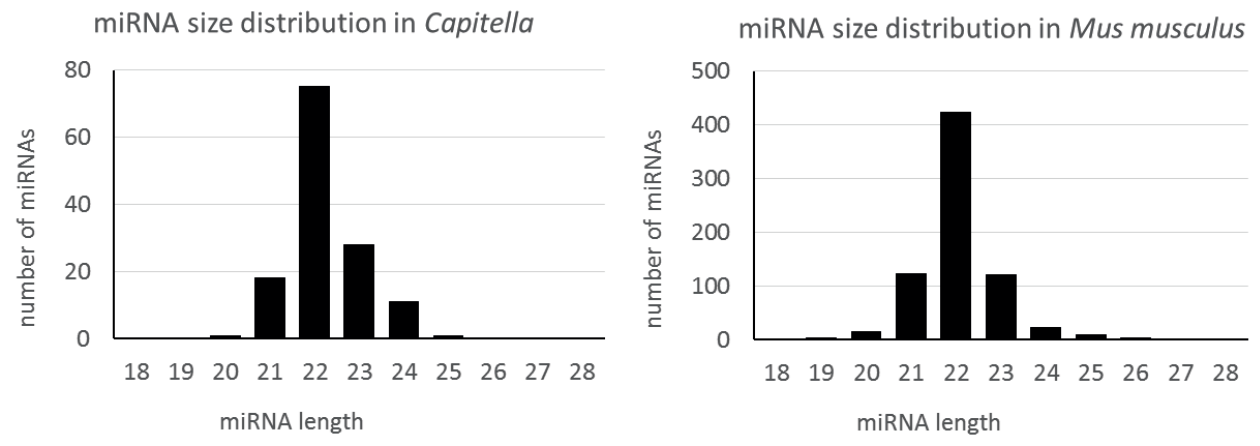

Figure 1 Annelid miRNA lengths

The left graph depicts size distribution of all 134 miRNAs of a polychaete worm Capitella teleta deposited in the miRBase (version 21). For comparison, the right graph shows size distribution of 721 high-confidence murine miRNAs.

(XM_009015681.1 and XM_009021522.1). The two paralogs of PIWI proteins would be consistent with the aforementioned analysis of Myzostoma cirriferum PIWI proteins (Weigert et al., 2013). Whether the two AGO paralogs are functionally dedicated to RNAi and miRNA pathways like AGO proteins in Drosophila is unknown. Furthermore, if annelids would have two PIWI proteins, it is possible that Capitella might have only one AGO protein serving in RNAi and miRNA pathways.

\section{Other factors}

No other proteins factors from miRNA or RNAi pathway have been specifically reported. Data from Rosani et al. show that annelids employ microprocessor complex (Rosani et al., 2016)

\section{miRNA}

There is one annelid species, which has annotated miRNAs in the miRBase: Capitella teleta -129 precursor miRNAs and 134 mature miRNAs. Literature search revealed seven publications reporting annelid miRNA identification and or expression (Christodoulou et al., 2010; Gong et al., 2010; Helm et al., 2012; Huang et al., 2012; Kenny et al., 2015; Sperling et al., 2009; Tessmar-Raible et al., 2007). As shown above, annelid miRNAs have an average length 22 nucleotides like other animal miRNAs.

\section{RNAi}

The only information available concerning RNAi is that it is functional (Takeo et al., 2010; Yoshida-Noro and Tochinai, 2010). The only one published experimental paper reporting RNAi employed long dsRNA that was injected into the coelom $(1 \mu \mathrm{g} / \mu \mathrm{l}, 100 \mathrm{nl}$ per worm, i.e. $100 \mathrm{ng}$ of dsRNA/worm). 


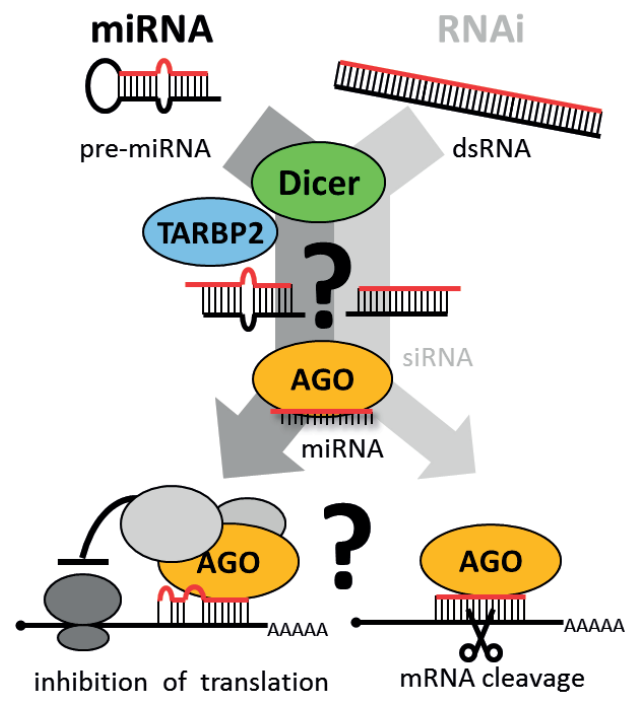

Figure 2 Overview of annelid pathways

dsRNA and miRNA pathways in annelids are poorly understood. Among the missing pieces of information are: 1) degree of separation of miRNA and RNAi pathways (dedicated AGO proteins, co-existence of Dicer isoforms). Proteins from other dsRNA pathways related to innate immunity include OAS, most likely RIG-I and MDA5 homologs but probably not PKR.

\section{Other dsRNA responding pathways}

Only one reference mentioned another protein involved in dsRNA response - OAS (Kjaer et al., 2009). Blast search for murine PKR, RIG-I, and MDA5 (algorithm: tblastn, database: Nucleotide collection $\mathrm{nr} / \mathrm{nt}$, results restricted to Annelida (taxid:6340)) revealed many sequences of Helobdella, and six of Platynereis, which were similar only to the second half of PKR, suggesting they were not orthologs. RIG-I and MDA5 searches identified two hypothetical proteins in Helobdella (ref|XM_009026626.1| and XM_009014668.1) with $\sim 35 \%$ identity and $\sim 50 \%$ similarity, which could be orthologs.

\section{Summary}

In terms of the molecular mechanism of dsRNA and miRNA pathways, annelids remain largely unexplored. While, the available information points towards coexistence of miRNA and RNAi pathways, their integration or genetic separation remain unclear.

\section{Molluscs}

Molluscs are a large and extremely diverse group of coelomate protostomes, which have an unsegmented soft body, internal or external shell, and a muscular foot. There are $\sim 50000$ 
described species, which makes molluscs the second largest phylum after Arthropoda (third if Chelicerata and Hexapoda would be considered separate phyla). Apart from the complex classification of molluscs into 7-10 classes, three groups of molluscs are commonly recognized: Cephalopoda (squid, octopus), Gastropoda (snails and slugs), and Bivalvia (clams, mussels, scallops, oysters). Literature on RNA silencing and dsRNA pathways is limited. There were 92 publications dealing with small RNAs, most of which was related to use of RNAi as an experimental tool for suppressing gene expression.

\section{Dicer}

There was no specific functional analysis of Dicer in molluscs. There is one study from 2016, which identified and bioinformatically analyzed Dicer and other components of miRNA and RNAi pathways in marine bivalves with a focus on a mussel Mytillus galloprovincialis and oyster Cassostrea gigas (Rosani et al., 2016). Their results show that all examined molluscs ( $>30$ species of cephalopods, gastropods, and bivalves) have a single Dicer protein, which participates in both, RNAi and miRNA pathways and that Dicer of Mytillus galloprovincialis and Cassostrea gigas has a common structure found in Metazoa.

Additional information regarding Dicer structure was extracted from genomic databases. Blast search of molluscs entries in Genbank (query: murine Dicer protein, algorithm: tblastn, database: Nucleotide collection $\mathrm{nr} / \mathrm{nt}$, results restricted to molluscs (taxid:6447)) identified transcripts from Mytilus, Crasostrea, Lottia, Aplysia, Miomphalaria, and Octopus that apparently encoded full-length Dicer orthologs. Molluscs Dicer also produces miRNAs with median length of 22 nucleotides as estimated from the miRBase data (Kozomara and Griffiths-Jones, 2014). Interestingly, the incidence of $23 \mathrm{nt}$ long miRNAs seems to be higher in molluscs (Fig. 3). However, given the low number of miRNAs (64) and unexplored diversity of molluses, it should not be considered a significant feature.

\section{dsRBPs}

There is no literature concerning dsRBP proteins participating in RNA silencing in molluscs. The above-mentioned analysis of miRNA and RNAi pathway components identified only a single dsRBP (TARBP2) homolog (Rosani et al., 2016).

\section{Argonaute proteins}

Likewise, there is essentially no information regarding the AGO subfamily of Argonaute proteins. The above-mentioned analysis of miRNA and RNAi pathway components identified one to four Argonaute proteins from both, AGO and PIWI clades (Rosani et al., 2016). However, general and derived roles of AGO proteins in molluscs remain unknown at the moment. Data from Mytillus galloprovincialis indicate presence of one AGO and two PIWI proteins (Rosani et al., 2016). This is remarkable because this AGO protein would act in both, RNAi and miRNA pathways like $\mathrm{AGO} 2$ in mammals.

In addition, there were two articles concerning the PIWI clade, which is acting in the piRNA pathway in the germline. In one of them, authors reported differential proteomic 

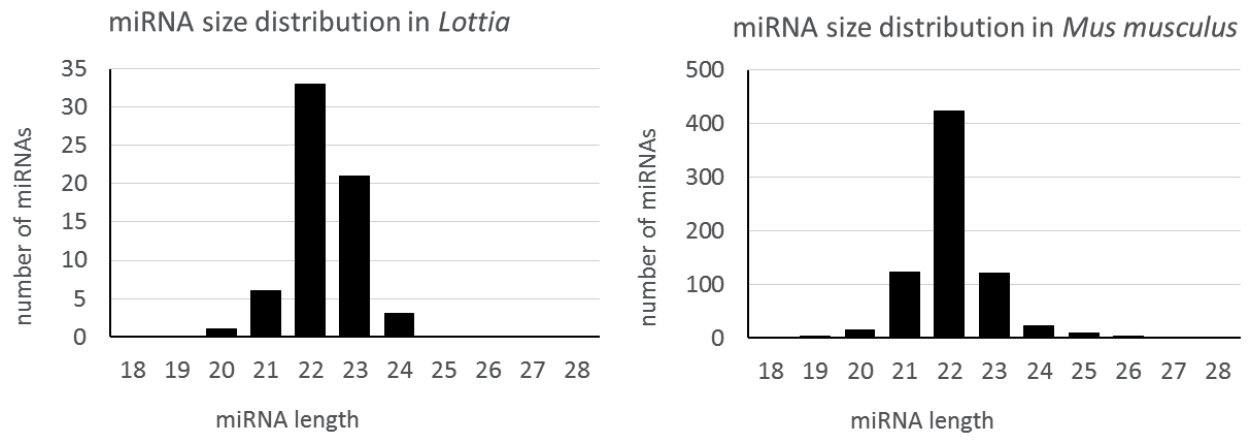

Figure 3 Molluscs miRNA lengths

The left graph depicts size distribution of all 64 miRNAs of sea snail Lottia gigantea deposited in the miRBase (version 21). For comparison, the right graph shows size distribution of 721 high-confidence murine miRNAs.

responses to generic dsRNA (poly I:C and poly A:U) in two oyster species (Saccostrea glomerata and Crassostrea gigas), which have differential susceptibility to ostreid herpesvirus infection. Interestingly, Saccostrea glomerata, which is not susceptible, showed production of proteins implicated in the TLR signalling pathway and PIWI protein was also found in Saccostrea glomerata but not in Crassostrea gigas when challenged with dsRNA (Masood et al., 2016). Although it is unclear whether PIWI could be mistaken for AGO, it is possible that piRNAs might have acquired additional roles in molluscs, perhaps including also immunity. This notion would be supported by the second report, which identified $28 \mathrm{nt}$ piRNAs in brain (while piRNAs are generally restricted to gonads if not into germline cells only). These piRNAs had unique biogenesis patterns, nuclear localization, sensitivity to serotonin, and were implicated in stable long-term changes in neurons associated with memory (Rajasethupathy et al., 2012).

\section{Other factors}

According to the genome analysis of Mytillus galloprovincialis, Precambrian molluscs/ mammalian ancestors must have shared all ancestral proteins in the miRNA pathway, including DROSHA, DGCR8 and GW182 (Rosani et al., 2016). There are no published mechanistic data suggesting that there would be any difference in activity of any of these factors in molluscs.

Importantly, we examined if molluscs genomes also contain an RdRP, which is found in RNA silencing in plants and Nematodes but not in insects or mammals: query: C. elegans RRF-1 NP_001250555, algorithm: tblastn, database: Nucleotide collection nr/nt, results restricted to molluscs (taxid:6447)) identified transcripts six different transcripts from Crassostrea gigas (XM_011450789, XM_011427600, XR_900019, XR_902698, XM_011450791, XR_900018) suggesting that molluscs might indeed employ RdRPs in RNAi. This would be a significant observation, making molluscs RNA silencing an intermediate type between those found in nematodes, arthropods, and mammals. 


\section{miRNA}

There is three molluscs species, which have annotated miRNAs in the miRBase (Kozomara and Griffiths-Jones, 2014): Haliotis rufescens (red abalone sea snail), Lottia gigantean (owl limpet sea snai)l, and Melibe leonine (lion nudibranch sea slug). Unfortunately, there are no other representatives of other main mollusk groups such as Cephalopodes or Bivalves. Annelid miRNAs have are $\sim 22 \mathrm{nt}$ long like other animal miRNAs (Fig. 4). There is a small number of reports concerning miRNA identification/annotation and/or analysis of expression/function in molluscs (Biggar et al., 2012; Bitel et al., 2012; Chen et al., 2014; Jiao et al., 2014; Jiao et al., 2015; Kenny et al., 2015; Martin-Gomez et al., 2014; Millan, 2011; Rajasethupathy et al., 2009; Tian et al., 2015; Xu et al., 2014; Zhao et al., 2016; Zheng et al., 2016a; Zheng et al., 2016b; Zhou et al., 2014).

\section{RNAi}

RNAi is functional in molluses as evidenced by 18 reports, which employed RNAi in different molluscs species (see the table below). The canonical RNAi (i.e. using long dsRNA) has been observed in the following species upon various forms of delivery including larva soaking, animal injection (adductor muscle, gonad, brain, larva, post-renal sinus etc.), polyethyleneimin-mediated delivery, or cell injection. Collectively, these data imply that different molluscs have an intact machinery to execute RNAi. Effects of injection into body cavity would suggest that molluscs might have some cellular uptake mechanism for dsRNA or systemic RNAi but the direct evidence for any of that is lacking at the moment. Other dsRNA responding pathways

Molluscs seem to have a complex dsRNA response, which includes interferon-like response functioning in antiviral response (reviewed in Green et al., 2015a; Wang et al., 2015b). 21 articles dealt with dsRNA-induced interferon-like response. Several studies in Oyster have reported that dsRNA mimic poly(I:C) can strongly induce non-specific antiviral immune responses (De Zoysa et al., 2007; Green and Barnes, 2009; Green and Montagnani, 2013; Green et al., 2015b; Masood et al., 2016; Wang et al., 2016b; Wang et al., 2016c).

Molluscs have 2'5'- oligoadenylate synthetases (Kjaer et al., 2009; Pari et al., 2014), RIG-I-like protein (Zhang et al., 2014), MDA5 (Green et al., 2014), and PKR (Green et al., 2014; Green and Montagnani, 2013; Green et al., 2015b). Poly I:C can be also bound by Leucine-rich repeat (LRR)-only protein found in scallop Chlamys farreri (Wang et al., 2016b; Wang et al., 2016c). Another gene, which is induced by poly I:C or sodium alginate is Myxovirus resistance (Mx) protein, which has been found in Abalone (Cheng et al., 2012; De Zoysa et al., 2007). Mx is one of intensely studied antiviral proteins, which is induced by the type I interferon system (IFN alpha/beta).

However, it is important to recognize that molluscs are a heterogeneous group with distinct antiviral adaptations. For example, proteomic profiling of two oyster species with differential susceptibility to ostreid herpesviruses showed that the resistant species has a stronger manifestation of the interferon-like response in the proteome upon induction with poly I:C (Masood et al., 2016). 


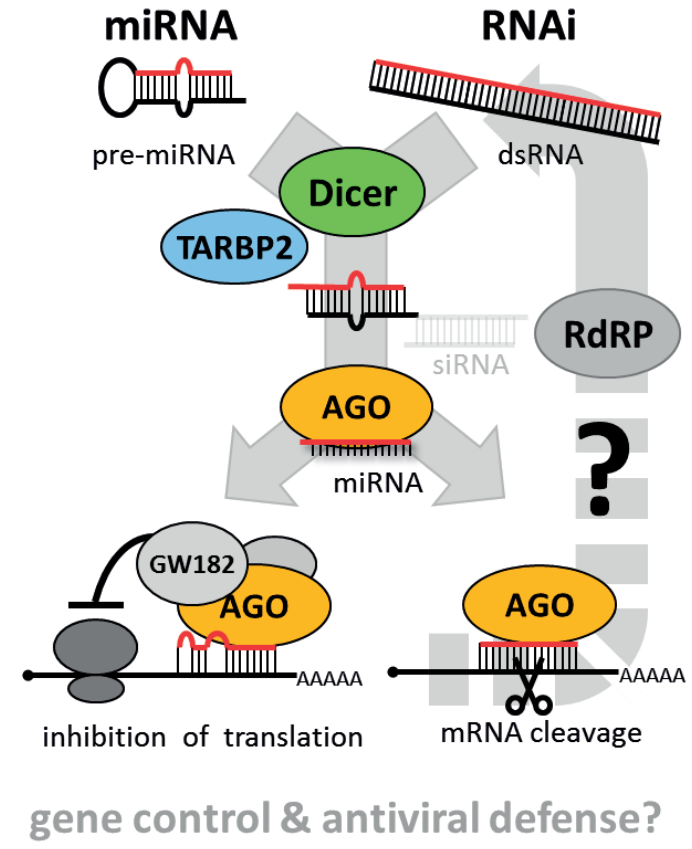

Figure 4 Overview of mollusc pathways

dsRNA and miRNA pathways in molluscs are poorly understood. Among the missing pieces of information are: 1) degree of separation of miRNA and RNAi pathways (dedicated AGO proteins, co-existence of Dicer isoforms). 2) existence and functionality of RdRPs in molluscs, 3) derived roles of piRNAs in gene regulation and antiviral defense. Proteins from other dsRNA pathways related to innate immunity include PKR, OAS, RIG-I and MDA5 homolog, Mx protein and others.

\section{Summary}

Taken together, molluscs are an interesting taxon, which appears to have a unique setup of RNA silencing (Fig. 4) and its nexus with antiviral responses, which warrant further investigation.

\section{Acknowledgement}

I would like to thank my colleagues Jan Paces, Miloslav Nic and Tomas Novotny for help with collecting literature for the review. The review content was produced under a contract OC/EFSA/GMO/2015/01-CT 01 with European Food Safety Authority (EFSA); the opinions expressed are those of the contractor only and do not represent EFSA's official position. Publication of the review was funded by LO1220 and LM2015063 by the Ministry of Education, Youth and Sports. 
Table 1 RNAi in molluscs induced with short dsRNA molecules

\begin{tabular}{|l|l|l|l|}
\hline species & siRNA amount & delivery method \& effect & reference \\
\hline Chlamys farreri & $1 \mu \mathrm{g} / \mathrm{g}$ & $\begin{array}{l}\text { adductor muscle siRNA injection } \\
70 \% \mathrm{KD} \text { at } 72 \mathrm{~h}\end{array}$ & (Miao et al., 2016) \\
\hline $\begin{array}{l}\text { Biomphalaria } \\
\text { glabrata }\end{array}$ & $772 \mathrm{ng} / 250 \mu \mathrm{l}$ & $\begin{array}{l}\text { polyethyleneimine-mediated delivery } \\
>50-90 \% \mathrm{KD} \text { at } 72 \mathrm{~h} \text { by ELISA }\end{array}$ & (Knight et al., 2011) \\
\hline Lymnaea stagnalis & $5 \mu \mathrm{l}$ of $200 \mathrm{ng} / \mu \mathrm{l}$ & $\begin{array}{l}\text { gonad injection, 27-mer } \\
30-50 \% \mathrm{KD}\end{array}$ & (Fei et al., 2007) \\
\hline Lymnaea stagnalis & $2 \mu \mathrm{l}$ of $20 \mu \mathrm{M}$ & $\begin{array}{l}\text { head injection above central ganglia, 27-mer, } \\
\text { (Hui et al., 2007) }\end{array}$ \\
\hline
\end{tabular}

Table 2 RNAi in molluscs induced with long dsRNA molecules

\begin{tabular}{|c|c|c|c|c|}
\hline \multirow[t]{2}{*}{ species } & \multicolumn{2}{|l|}{ long dsRNA } & \multirow{2}{*}{ delivery method } & \multirow{2}{*}{ reference } \\
\hline & concentration & length & & \\
\hline $\begin{array}{l}\text { Haliotis } \\
\text { diversicolor }\end{array}$ & $5 \mu \mathrm{g} / \mathrm{ml}$ & $136-819 \mathrm{bp}$ & larva soaking & (Wang et al., 2016a) \\
\hline $\begin{array}{l}\text { Haliotis } \\
\text { diversicolor }\end{array}$ & $5 \mu \mathrm{g} / \mathrm{ml}$ & $136-819 \mathrm{bp}$ & larva soaking & (Wang et al., 2015a) \\
\hline $\begin{array}{l}\text { Crassostrea } \\
\text { gigas }\end{array}$ & $\begin{array}{l}150-750 \mu \mathrm{g} / \mathrm{ml} \\
10 \mu \mathrm{g} / \mathrm{g}\end{array}$ & $652 \mathrm{bp}$ & $\begin{array}{l}2 \times 100 \mu l \text { injection } \\
\sim 50 \% \mathrm{KD} \text { at } 48 \mathrm{~h}\end{array}$ & (Huvet et al., 2015) \\
\hline $\begin{array}{l}\text { Crassostrea } \\
\text { gigas }\end{array}$ & $50 \mu \mathrm{g} /$ oyster & 723 bp & $\begin{array}{l}\text { adductor muscle inject. } \\
1-7 \text { days, good effect }\end{array}$ & (Choi et al., 2013) \\
\hline $\begin{array}{l}\text { Crassostrea } \\
\text { gigas }\end{array}$ & $\begin{array}{l}530 \mu \mathrm{g} / \mathrm{ml} \\
53 \mu \mathrm{g} / \text { oyster }\end{array}$ & $425 \mathrm{bp}$ & $\begin{array}{l}\text { gonad injection } \\
77.52 \% \mathrm{KD}\end{array}$ & (Huvet et al., 2012) \\
\hline $\begin{array}{l}\text { Nipponacmea } \\
\text { fuscoviridis }\end{array}$ & $5 \mu \mathrm{g} / \mathrm{ml}$ & $\begin{array}{l}947 \mathrm{bp} \\
667 \mathrm{bp}\end{array}$ & larva injection & $\begin{array}{l}\text { (Hashimoto } \\
\text { et al., 2012) }\end{array}$ \\
\hline Aplysia & $500 \mathrm{ng} / \mu \mathrm{l}$ & $316 \mathrm{bp}$ & $\begin{array}{l}\text { sensory cell injection } \\
\text { protein not decreased }\end{array}$ & (Lyles et al., 2006) \\
\hline $\begin{array}{l}\text { Lymnaea } \\
\text { stagnalis }\end{array}$ & $\begin{array}{l}500 \mathrm{ng} / \mu 1 \\
2 \mu \mathrm{g} / \text { oyster } \\
\end{array}$ & $\sim 300 \mathrm{bp}$ & $\begin{array}{l}\text { central ring ganglia } \\
60 \% \mathrm{KD} \text { at } 24 \mathrm{~h}\end{array}$ & (Guo et al., 2010) \\
\hline $\begin{array}{l}\text { Lymnaea } \\
\text { stagnalis }\end{array}$ & $5 \mu \mathrm{l}$ of $200 \mathrm{ng} / \mu \mathrm{l}$ & $321 \mathrm{bp}$ & $\begin{array}{l}\text { snail ganglia injection } \\
30-50 \% \mathrm{KD}\end{array}$ & (Fei et al., 2007) \\
\hline $\begin{array}{l}\text { Crassostrea } \\
\text { gigas. }\end{array}$ & 20 or $100 \mu \mathrm{g} /$ oyster & $\begin{array}{l}525 \mathrm{bp} \\
877 \mathrm{bp}\end{array}$ & $\begin{array}{l}\text { gonad injection } \\
39 \% \& 87 \% \mathrm{KD}\end{array}$ & (Fabioux et al., 2009) \\
\hline $\begin{array}{l}\text { Biomphalaria } \\
\text { glabrata }\end{array}$ & $0.1,1.0$ and $5.0 \mu \mathrm{g} / \mathrm{snail}$ & $\begin{array}{l}537 \mathrm{bp} \\
541 \mathrm{bp}\end{array}$ & $\begin{array}{l}\text { post-renal sinus inj. } \\
70-80 \% \mathrm{KD}\end{array}$ & (Jiang et al., 2006) \\
\hline $\begin{array}{l}\text { Biomphalaria } \\
\text { glabrata }\end{array}$ & $120 \mathrm{ng} / 250 \mu \mathrm{l}$ & 397 bp & $\begin{array}{l}\text { polyethyleneimine-mediated } \\
\text { delivery } \\
>50 \% \mathrm{KD} \text { at } 72 \mathrm{~h} \text { by ELISA. }\end{array}$ & (Knight et al., 2011) \\
\hline Aplysia & $500 \mathrm{ng} / \mu \mathrm{l}$ & $316 \mathrm{bp}$ & $\begin{array}{l}\text { sensory cell injection } \\
\text { protein not decreased }\end{array}$ & (Lyles et al., 2006) \\
\hline Aplysia & up to $700 \mu \mathrm{g} / \mathrm{mL}$ & N.A. & $\begin{array}{l}\sim 20 \text { giant neurons of the } \\
\text { abdominal ganglion inj., } \\
80-95 \% \text { KD }\end{array}$ & (Lee et al., 2001) \\
\hline Aplysia & $500 \mu \mathrm{g} / \mathrm{mL}$ & 800 bp & $\begin{array}{l}\text { sensory neuron injection } \\
\text { decrease by microscopy }\end{array}$ & (Ormond et al., 2004) \\
\hline
\end{tabular}




\section{References}

Bartel, D.P. (2018). Metazoan MicroRNAs. Cell 173, 20-51.

Biggar, K.K., Kornfeld, S.F., Maistrovski, Y., and Storey, K.B. (2012). MicroRNA Regulation in Extreme Environments: Differential Expression of MicroRNAs in the Intertidal Snail Littorina littorea During Extended Periods of Freezing and Anoxia. Genomics Proteomics \& Bioinformatics 10, 302-309.

Bitel, C.L., Singh, V., and Frederikse, P.H. (2012). miR-124, miR-125b, let-7 and Vesicle Transport Proteins in Squid Lenses in L. pealei. Current Eye Research 37, 388-394.

Chen, G.F., Zhang, C.Y., Jiang, F.J., Wang, Y.Y., Xu, Z., and Wang, C.M. (2014). Bioinformatics analysis of hemocyte miRNAs of scallop Chlamys farreri against acute viral necrobiotic virus (AVNV). Fish \& Shellfish Immunology 37, 75-86.

Cheng, W., Tsai, R.T., and Chang, C.C. (2012). Dietary sodium alginate administration enhances Mx gene expression of the tiger grouper, Epinephelus fuscoguttatus receiving poly I:C. Aquaculture 324, 201-208.

Choi, S.H., Jee, B.Y., Lee, S.J., Cho, M.Y., Lee, S.J., Kim, J.W., Do Jeong, H., and Kim, K.H. (2013). Effects of RNA interference-mediated knock-down of hypoxia-inducible factor-alpha on respiratory burst activity of the Pacific oyster Crassostrea gigas hemocytes. Fish \& Shellfish Immunology 35, 476-479.

Christodoulou, F., Raible, F., Tomer, R., Simakov, O., Trachana, K., Klaus, S., Snyman, H., Hannon, G.J., Bork, P., and Arendt, D. (2010). Ancient animal microRNAs and the evolution of tissue identity. Nature 463, 1084-U1105.

De Zoysa, M., Kang, H.S., Song, Y.B., Jee, Y., Lee, Y.D., and Lee, J. (2007). First report of invertebrate Mx: Cloning, characterization and expression analysis of Mx cDNA in disk abalone (Haliotis discus discus). Fish \& Shellfish Immunology 23, 86-96.

Fabioux, C., Corporeau, C., Quillien, V., Favrel, P., and Huvet, A. (2009). In vivo RNA interference in oyster-vasa silencing inhibits germ cell development. Febs Journal 276, 2566-2573.

Fei, G.H., Guo, C.H., Sun, H.S., and Feng, Z.P. (2007). Chronic hypoxia stress-induced differential modulation of heat-shock protein 70 and presynaptic proteins. Journal of Neurochemistry 100, 50-61.

Flemr, M., Malik, R., Franke, V., Nejepinska, J., Sedlacek, R., Vlahovicek, K., and Svoboda, P. (2013). A Retrotransposon-Driven Dicer Isoform Directs Endogenous Small Interfering RNA Production in Mouse Oocytes. Cell 155, 807-816.

Giani, V.C., Yamaguchi, E., Boyle, M.J., and Seaver, E.C. (2011). Somatic and germline expression of piwi during development and regeneration in the marine polychaete annelid Capitella teleta. Evodevo 2, 10-10.

Gong, P., Xie, F.L., Zhang, B.H., and Perkins, E.J. (2010). In silico identification of conserved microRNAs and their target transcripts from expressed sequence tags of three earthworm species. Computational Biology and Chemistry 34, 313-319.

Green, T.J., and Barnes, A.C. (2009). Inhibitor of REL/NF-B-K is regulated in Sydney rock oysters in response to specific double-stranded RNA and Vibrio alginolyticus, but the major immune anti-oxidants EcSOD and Prx6 are non-inducible. Fish \& Shellfish Immunology 27, 260-265.

Green, T.J., Benkendorff, K., Robinson, N., Raftos, D., and Speck, P. (2014). Anti-viral gene induction is absent upon secondary challenge with double-stranded RNA in the Pacific oyster, Crassostrea gigas. Fish \& Shellfish Immunology 39, 492-497. 
Green, T.J., and Montagnani, C. (2013). Poly I:C induces a protective antiviral immune response in the Pacific oyster (Crassostrea gigas) against subsequent challenge with Ostreid herpesvirus (OsHV-1 mu var). Fish \& Shellfish Immunology 35, 382-388.

Green, T.J., Raftos, D., Speck, P., and Montagnani, C. (2015a). Antiviral immunity in marine molluscs. Journal of General Virology 96, 2471-2482.

Green, T.J., Rolland, J.L., Vergnes, A., Raftos, D., and Montagnani, C. (2015b). OsHV-1 countermeasures to the Pacific oyster's anti-viral response. Fish \& Shellfish Immunology 47, 435-443.

Guo, C.H., Senzel, A., Li, K., and Feng, Z.P. (2010). De Novo Protein Synthesis of Syntaxin-1 and Dynamin-1 in Long-Term Memory Formation Requires CREB1 Gene Transcription in Lymnaea stagnalis. Behavior Genetics 40, 680-693.

Hashimoto, N., Kurita, Y., and Wada, H. (2012). Developmental role of dpp in the gastropod shell plate and co-option of the dpp signaling pathway in the evolution of the operculum. Developmental Biology 366, 367-373.

Helm, C., Bernhart, S.H., Siederdissen, C.H.Z., Nickel, B., and Bleidorn, C. (2012). Deep sequencing of small RNAs confirms an annelid affinity of Myzostomida. Molecular Phylogenetics and Evolution 64, 198-203.

Huang, X.M., Tian, Q.N., Bao, Z.X., Qin, Y.F., Chen, S.J., Lu, P., Zhang, X.L., Zhang, Y.Z., and Zhang, S.T. (2012). Cloning and Identification of MicroRNAs in Earthworm (Eisenia fetida). Biochemical Genetics 50,1-11.

Hui, K., Fei, G.H., Saab, B.J., Su, J., Roder, J.C., and Feng, Z.P. (2007). Neuronal calcium sensor-1 modulation of optimal calcium level for neurite outgrowth. Development 134, 4479-4489.

Huvet, A., Beguel, J.P., Cavaleiro, N.P., Thomas, Y., Quillien, V., Boudry, P., Alunno-Bruscia, M., and Fabioux, C. (2015). Disruption of amylase genes by RNA interference affects reproduction in the Pacific oyster Crassostrea gigas. Journal of Experimental Biology 218, 1740-1747.

Huvet, A., Fleury, E., Corporeau, C., Quillien, V., Daniel, J.Y., Riviere, G., Boudry, P., and Fabioux, C. (2012). In Vivo RNA Interference of a Gonad-Specific Transforming Growth Factor-beta in the Pacific Oyster Crassostrea gigas. Marine Biotechnology 14, 402-410.

Jiang, Y.G., Loker, E.S., and Zhang, S.M. (2006). In vivo and in vitro knockdown of FREP2 gene expression in the snail Biomphalaria glabrata using RNA interference. Developmental and Comparative Immunology 30, 855-866.

Jiao, Y., Zheng, Z., Du, X.D., Wang, Q.H., Huang, R.L., Deng, Y.W., Shi, S.L., and Zhao, X.X. (2014). Identification and Characterization of MicroRNAs in Pearl Oyster Pinctada martensii by Solexa Deep Sequencing. Marine Biotechnology 16, 54-62.

Jiao, Y., Zheng, Z., Tian, R.R., Du, X.D., Wang, Q.H., and Huang, R.L. (2015). MicroRNA, Pm-miR-2305, Participates in Nacre Formation by Targeting Pearlin in Pearl Oyster Pinctada martensii. International Journal of Molecular Sciences 16, 21442-21453.

Kenny, N.J., Namigai, E.K.O., Marletaz, F., Hui, J.H.L., and Shimeld, S.M. (2015). Draft genome assemblies and predicted microRNA complements of the intertidal lophotrochozoans Patella vulgata (Mollusca, Patellogastropoda) and Spirobranchus (Pomatoceros) lamarcki (Annelida, Serpulida). Marine Genomics 24, 139-146.

Kjaer, K.H., Poulsen, J.B., Reintamm, T., Saby, E., Martensen, P.M., Kelve, M., and Justesen, J. (2009). Evolution of the 2'-5'-Oligoadenylate Synthetase Family in Eukaryotes and Bacteria. Journal of Molecular Evolution 69, 612-624. 
Knight, M., Miller, A., Liu, Y.J., Scaria, P., Woodle, M., and Ittiprasert, W. (2011). Polyethyleneimine (PEI) Mediated siRNA Gene Silencing in the Schistosoma mansoni Snail Host, Biomphalaria glabrata. Plos Neglected Tropical Diseases 5, e1212-e1212.

Kozin, V.V., and Kostyuchenko, R.P. (2015). Vasa, PL10, and Piwi gene expression during caudal regeneration of the polychaete annelid Alitta virens. Development Genes and Evolution 225, $129-138$.

Kozomara, A., and Griffiths-Jones, S. (2014). miRBase: annotating high confidence microRNAs using deep sequencing data. Nucleic Acids Res 42, D68-73.

Lee, J.A., Kim, H.K., Kim, K.H., Han, J.H., Lee, Y.S., Lim, C.S., Chang, D.J., Kubo, T., and Kaang, B.K. (2001). Overexpression of and RNA interference with the CCAAT enhancer-binding protein on long-term facilitation of Aplysia sensory to motor synapses. Learning \& Memory 8, 220-226.

Lyles, V., Zhao, Y.L., and Martin, K.C. (2006). Synapse formation and mRNA localization in cultured Aplysia neurons. Neuron 49, 349-356.

Martin-Gomez, L., Villalba, A., Kerkhoven, R.H., and Abollo, E. (2014). Role of microRNAs in the immunity process of the flat oyster Ostrea edulis against bonamiosis. Infection Genetics and Evolution 27, 40-50.

Masood, M., Raftos, D.A., and Nair, S.V. (2016). Two oyster species that show differential susceptibility to virus infection also show differential proteomic responses to generic dsRNA. Journal of proteome research.

Miao, G., Qi, H., Li, L., Que, H., and Zhang, G. (2016). Characterization and functional analysis of two inhibitor of apoptosis genes in Zhikong scallop Chlamys farreri. Developmental and comparative immunology $60,1-11$.

Millan, M.J. (2011). MicroRNA in the regulation and expression of serotonergic transmission in the brain and other tissues. Current Opinion in Pharmacology 11, 11-22.

Ormond, J., Hislop, J., Zhao, Y.L., Webb, N., Vaillaincourt, F., Dyer, J.R., Ferraro, G., Barker, P., Martin, K.C., and Sossin, W.S. (2004). ApTrkl, a Trk-like receptor, mediates serotonin-dependent ERK activation and long-term facilitation in Aplysia sensory neurons. Neuron 44, 715-728.

Ozpolat, B.D., and Bely, A.E. (2015). Gonad establishment during asexual reproduction in the annelid Pristina leidyi. Developmental Biology 405, 123-136.

Pari, M., Kuusksalu, A., Lopp, A., Kjaer, K.H., Justesen, J., and Kelve, M. (2014). Enzymatically active 2 ', 5 ' -oligoadenylate synthetases are widely distributed among Metazoa, including protostome lineage. Biochimie 97, 200-209.

Rajasethupathy, P., Antonov, I., Sheridan, R., Frey, S., Sander, C., Tuschl, T., and Kandel, E.R. (2012). A Role for Neuronal piRNAs in the Epigenetic Control of Memory-Related Synaptic Plasticity. Cell 149, 693-707.

Rajasethupathy, P., Fiumara, F., Sheridan, R., Betel, D., Puthanveettil, S.V., Russo, J.J., Sander, C., Tuschl, T., and Kandel, E. (2009). Characterization of Small RNAs in Aplysia Reveals a Role for miR-124 in Constraining Synaptic Plasticity through CREB. Neuron 63, 803-817.

Rosani, U., Pallavicini, A., and Venice, P. (2016). The miRNA biogenesis in marine bivalves. Peerj 4, e1763-e1763.

Sperling, E.A., Vinther, J., Moy, V.N., Wheeler, B.M., Semon, M., Briggs, D.E.G., and Peterson, K.J. (2009). MicroRNAs resolve an apparent conflict between annelid systematics and their fossil record. Proceedings of the Royal Society B-Biological Sciences 276, 4315-4322. 
Sugio, M., Takeuchi, K., Kutsuna, J., Tadokoro, R., Takahashi, Y., Yoshida-Noro, C., and Tochinai, S. (2008). Exploration of embryonic origins of germline stem cells and neoblasts in Enchytraeus japonensis (Oligochaeta, Annelida). Gene Expression Patterns 8, 227-236.

Svoboda, P. (2019). Introduction to RNAi and miRNA pathways.

Takeo, M., Yoshida-Noro, C., and Tochinai, S. (2010). Functional analysis of grimp, a novel gene required for mesodermal cell proliferation at an initial stage of regeneration in Enchytraeus japonensis (Enchytraeidae, Oligochaete). International Journal of Developmental Biology 54, 151-160.

Tessmar-Raible, K., Raible, F., Christodoulou, F., Guy, K., Rembold, M., Hausen, H., and Arendt, D. (2007). Conserved sensory-neurosecretory cell types in annelid and fish forebrain: Insights into hypothalamus evolution. Cell 129, 1389-1400.

Tian, R.R., Zheng, Z., Huang, R.L., Jiao, Y., and Du, X.D. (2015). miR-29a Participated in Nacre Formation and Immune Response by Targeting Y2R in Pinctada martensii. International Journal of Molecular Sciences 16, 29436-29445.

Wang, G.D., Li, N., Zhang, L.L., Zhang, L.H., Zhang, Z.P., and Wang, Y.L. (2015a). IGFBP7 promotes hemocyte proliferation in small abalone Haliotis diversicolor, proved by dsRNA and cap mRNA exposure. Gene 571, 65-70.

Wang, G.D., Li, N., Zhang, L.L., Zhang, L.H., Zhang, Z.P., and Wang, Y.L. (2016a). IGFBP7 is involved in abalone metamorphosis. Aquaculture 451, 377-384.

Wang, M., Wang, L., Xin, L., Wang, X., Wang, L., Xu, J., Jia, Z., Yue, F., Wang, H., and Song, L. (2016b). Two novel LRR-only proteins in Chlamys farreri: Similar in structure, yet different in expression profile and pattern recognition. Developmental and Comparative Immunology 59, 99-109.

Wang, M.Q., Wang, L.L., Guo, Y., Yi, Q.L., and Song, L.S. (2016c). An LRR-only protein representing a new type of pattern recognition receptor in Chlamys farreri. Developmental and Comparative Immunology 54, 145-155.

Wang, P.H., Weng, S.P., and He, J.G. (2015b). Nucleic acid-induced antiviral immunity in invertebrates: An evolutionary perspective. Developmental and Comparative Immunology 48, 291-296.

Weigert, A., Helm, C., Hausen, H., Zakrzewski, A.C., and Bleidorn, C. (2013). Expression pattern of Piwi-like genes in adult Myzostoma cirriferum (Annelida). Development Genes and Evolution 223, 329-334.

Xu, F., Wang, X.T., Feng, Y., Huang, W., Wang, W., Li, L., Fang, X.D., Que, H.Y., and Zhang, G.F. (2014). Identification of Conserved and Novel MicroRNAs in the Pacific Oyster Crassostrea gigas by Deep Sequencing. Plos One 9, e104371-e104371.

Yoshida-Noro, C., and Tochinai, S. (2010). Stem cell system in asexual and sexual reproduction of Enchytraeus japonensis (Oligochaeta, Annelida). Development Growth \& Differentiation 52, $43-55$.

Zhang, Y., Yu, F., Li, J., Tong, Y., Zhang, Y.H., and Yu, Z.N. (2014). The first invertebrate RIG-I-like receptor (RLR) homolog gene in the pacific oyster Crassostrea gigas. Fish \& Shellfish Immunology 40, 466-471.

Zhao, X.L., Yu, H., Kong, L.F., Liu, S.K., and Li, Q. (2016). High throughput sequencing of small RNAs transcriptomes in two Crassostrea oysters identifies microRNAs involved in osmotic stress response. Scientific Reports 6, 22687-22687. 
Zheng, Z., Jiao, Y., Du, X.D., Tian, Q.L., Wang, Q.H., Huang, R.L., and Deng, Y.W. (2016a). Computational prediction of candidate miRNAs and their potential functions in biomineralization in pearl oyster Pinctada martensii. Saudi Journal of Biological Sciences 23, 372-378.

Zheng, Z., Liang, J., Huang, R., Du, X., Wang, Q., Deng, Y., and Jiao, Y. (2016b). Identification of a novel miR-146a from Pinctada martensii involved in the regulation of the inflammatory response. Fish and Shellfish Immunology 54, 40-45.

Zhou, Z., Wang, L.L., Song, L.S., Liu, R., Zhang, H., Huang, M.M., and Chen, H. (2014). The Identification and Characteristics of Immune-Related MicroRNAs in Haemocytes of Oyster Crassostrea gigas. Plos One 9, e88397-e88397. 